
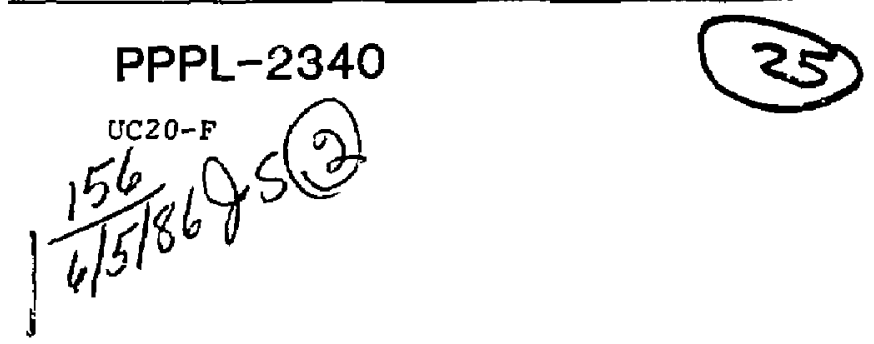

PPPL-2340

DE86 011166

\title{
HIGH TIME RESOLUTION ION TEMPERATURE PROFILE MEASUREMENTS ON PBX
}

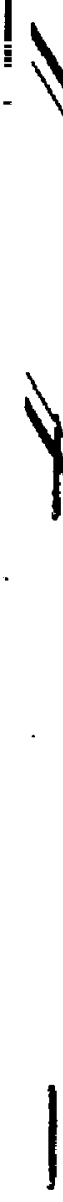

By

G. Gamnel, R. Kaita, R, Fonck,

K. Jaehnig, and E. Powell

MAY 1986

\section{PIJASMA PHYSICS \\ LABORATORY}

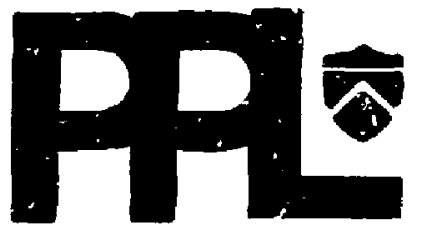

PRINCETON UNIVERSITY

PRINCETON, NEW JERSEY

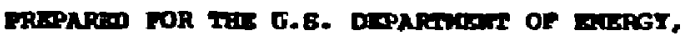
UIDER COTERACT DT-MCO2-76-C:0-3073. 
This report was prepared as an account of work sponsored by the United States Covernment. Neither the United States nor the United States Department of Energy, nor any of their employees, nor any of their contractors, subcontractors, or their employees, makes any warranty, express or implied, or assumes any legal liability or responsibflity for the accuracy, completeness or usefulness of any information, apparatus, product or process disclosed, or represents that its use would not infringe privately swned rights.

Printed in the United States of America

Available from:

National Technical Information Service U.S. Department of Commerce 5285 Port Royal Road Springfield, Virginia 22761

Price Printed Copy $\$ \ldots+$; Microfiche $\$ 4.50$

\section{* Pages}

$1-25$

25-50

$51-75$

76-100

901-125

126-150

$151-175$

$176 \div 200$

201-225

226-250

25?-275

276-300

$301-325$

326-350

$35 ?-375$

$376-400$

$401-425$

$426-450$

$451-475$

476-500

500-525

$526-550$

551-5.75

$567-600$

NTIS

Selling Price

$\$ 7.00$

$\$ 8.50$

$\$ 10.00$

$\$ 11.50$

$\$ 13.00$

$\$ 14.50$

$\$ 16.00$

$\$ 17.50$

$\$ 19.00$

$\$ 20.50$

$\$ 22.00$

$\$ 23.50$

$\$ 25.00$

$\$ 26.50$

$\$ 28.00$

$\$ 29.50$

$\$ 31.00$

$\$ 32.50$

$\$ 34.00$

$\$ 35.50$

$\$ 37.00$

$\$ 38.50$

$\$ 40.00$

$\$ 41,50$
For documents over 600 pages, add $\$ 1.50$ for each additional 25-page increment. 
HIGH TIME RESOLUTION ION TEMPERATURE

PROFILE MEASUREMENTS ON PBX

MASTER

G. Gamme1, R. Kaita, R. Fonck,

K. Jaehnig, and E. Powel1

\author{
PIasma Physics Laboratory \\ Princeton University \\ Princeton, New Jersey 08544
}

\begin{abstract}
Ion temperature profiles with a time resolution of $2-5$ ms have been measured on PBX by cherge-exchange-recombination spectroscopy (CXRS) and a neutral-particle charge-exchange analyzer (NPA). The sightlines of both diagnostics crossed the trajectory of a near-perpendicular heating beam, which enhanced the local neutral density ( $\alpha$ signal strength) and provided spatial resolution. The time resolution of these two independent techniques is sufficient to sez sawtooth oscillations and other MHD activity. Effects of these phenomena on the toroidal rotatich velocity profile, $v(r)$, are clearly observed by cXRS. For example, a sharp drop in the central $v_{\phi}$ occurs at the sawtooth crash, Eollowed by a linear rise during the quiescent phase. The NPA results are compared with those from CXRS.
\end{abstract}




\section{IFTRODUCTIOH}

The ability to measure changes in plasma ion temperatures on the relatively short time scale of a few insec is of special toterest in studies of low-q high-s plasmas, such as those produced in the Princeton Beta Experiment (PEX) ${ }^{1}$ rokauak. At low-q, sawtooth amplitudes can become large, and the affected plasma region extends over most of the radial profile, while rapidly changing MHD behavior and plasma rotation are often characteristics of high- $R$ discharges. In both cases, the determination of ion temperature profiles requires high time resolution in order to study ion thermal transport.

To that end, two complementary techniques to measure ion temperature profiles with high time resolution, one based on charge-exchange-recombination spectroscopy (CXRs) and the other on charge-exchange neutral-particle analysis, have been refined and compared. GXRs has been described in detail elsewhere, 2 but the present work also includes profile results. The second technique utilizes the neutral particle analyzer of the Fast Ion Diagnostic Experiment (FIDE). 3 Brief descríptions of the two techniques follow.

In CXRS, fully ionized impurity ions undergo charge exchange with fast neutrals ( $H^{\circ}$ or $D^{\circ}$ ) injected by the heating heams. One of the near-perpendicularly infected heating beams was used for the lesults obtained in PBX. The fully ionized impurity becomes a hydrogenlike impurity in an excited state, which consequently emits spectral lines anywhere from the extreme ultraviolet to the visible as it radiatively decays. Radiation from intrinsic impurtties, such as the $0^{7+}$ transition at $2976 A^{3}(n=8-7)$, can be used conventently. Ion temperacures are deduced from the line width, and toroidal rotation velocity from the 
line shift. Radial profiles for temperature ats toroidal rotation velocity are generated an a shot-by-shot basis by changing the spectrometer sightline. The radial points are those corresponding to the intersection of the various sightlines with the heating beam trajectory.

The optical system for CXRS on PBX consists of an $f / 10$ l-m Ebert spectrometer which is quartz lens coupled to view the plagma through a quartz window. An optical multichannel analyzer, consisting of a proximity-focused microchamel plate image intensifier fiber optically coupled to a 1024 element photodiode array, is used as the detector. 2 The readout and control electronics are similar to those described by Fonck, Ramsy, and Yelle.4 Jsing the maximum available entrance slit didth of $2200 \mu$ m, and grouping the pixel readout in groups of 4 pixels each, allowed sufficient signal and readout time to provide accurate 1ine profiles every 2 msec. This was found to be adequate to resolve sawtooth activity in the central ion temperature and toroidal rotation velocity.

The FIDE analyzer detects thernal charge-exchange neutrals, and can thus be used to determine lon cemperatures. With the analyzer in its mos tangential position, three of its five sightlines span the plasma from near its center to its outaide edge. Neutral particles entering the analyzer pass through a helium gas cell, and a fraction of them are re-ionized. That fraction passes through a pair of deflection plates and are detected by a micsochannel plate array. Their energy is determined by the deflection plate voltage, which is swept as a function of time. To study thermal neutrals, the plate voltage is swept over a range of 0 to $1-2 \mathrm{kV}$, which corregponds to ion energies between 
0 and $10-20 \mathrm{keV}$. The signal is integrated over $50 \mu \mathrm{s}$ intervals to accumulate sufficient statistics, and with this integration time a flux vs. energy plot can be obtained for sweep periods as fast as $2.5 \mathrm{~ms}$ (i.e., 50 points/sweep). The temporal resolution of the ion temperature measurement is thus determined by the sweep time, and is similar to CXRS.

An advantage of this analyzer is that temperatures can be measured simultaneously along as many as five sightlines. This allowed the evalution of radial profiles to be followed during a single shot with high temporal resolution, and three sightines were instrumented to obtain the measurements presented in this paper. The principal disadvantage is that the measured temperature is artificially high due to contamination from the slowing-down beam ions. However, the time evolution and the profile shapes of the two techniques are qualitatively similar. It should be noted that the FIDE signals are strongly enhanced (by a factor of 10 to 30 ) when viewing across the heating beam. As in CXRS, this is because the beam neutrals increase the local charge-exchange rate, and the measurements are then effectively localized to the intersections of the FIDE sightlines and the heathin beam trajectory.

\section{IT. DATA AND AHALYSIS}

Figures 1,a, and 1,b. show the time evolution of the central toroidal rotation velocity, $v_{\phi}(r=0)$, and the central fon temperature, $T_{1}(r=0)$, messured by CXRS with a temporal resolution of $4 \mathrm{~ms}$, for a discharge with strong sawtooth activity. Figires 1.c. and 1.d. show sample Gaussian fics to the data at two particular times, before and after the crash. The characteristic sattooth activity is clearly seen on both $T_{i}(r=0)$ and $v_{\phi}(r=0)$. 
Figure 2.a. shows raw EIux vs. tiate from FIDE just before and just after a sawtooth crash, digitized every 50 us. Also shown is che energy corresponding to the deflection plate voltage. Figure $2 . b$. shows the flux vs. energy plots that are constructed from the data in Fig. 2.a. and corrected for ionization efficiency of the gas cell and energy bandwidth of the analyzer. On a log scale, the plot should be linear for Maxwellian distributions, and the inverse slope gives the temperature. 5 Figure 2 shows that the temperature and the energy corresponding to peak flux both decrease after the sawtooth crash. The time dependence of the temperature fron cxRs and the three FIDE sightines are compared in detail around the time nf a sawtooth crash in Fig. 3. The toroidal rotation velocity (at $r=1 \mathrm{~cm}$ ) as a function of cime appears similar to fig. 3.a., dropping from $1.3 \times 10^{7}$ cal $/ \mathrm{sec}$ before the crash to $1.0 \times 10^{7} \mathrm{~cm} / \mathrm{sec}$ after, and then gradually increasing again. Radial temperacure profiles are shown fn Fig. 3.c. for times before and after the gawtooth crash.

The FIDE ia. temperatures are generally higi:er than the cXRS ion temperatures, especially in the plasma ccre reglon. This is presumably due to contanination from the slowing-down beating heam particles, as illustrated in F1g. 4. FIDE dota from the three sightines are shown in Flg. 4.a., and results of a Fokker-Planck sinulation of che FIDE spectrum uging the plasma parameters for the same shot aze shown in Fig. 4.b. Both the simulation and the data show curvaturt in the LN(F) plota over the same energy range. In the gimulation, this curvature is due to the beam ton contributior. The curvature becomes less severe in the simulation and the data for sightlineg closer to the plasma edge. Indeed, the quanticative agreement between CXRS and FIDE is best in this region. 


\section{SURGGARY}

Ion cemperatcures have been determined in PBX with high time resolution (2-5 uns) using two independent methods. The evolution af the temperature profiles can be measured by the FIDE analyzer on the same time scale, and the results are in qualitative agreement with cXRS profiles accumulated on a shot-by-shot basis. Ion temperarure and plasma rotation measurements show sawtooth oscillations similar to those seen in the electron temperature. Contamination of the FIDE analyzer energy spectrum from slowing-down heating beam particles is the primary cause of the quantitative discrepancy between the two techniques.

\section{ACTOYOHLEDGMENTS}

We thanix $S$. Kaye for performing a TRANSP simulation of some of the data in this paper.

This work was supporeed by 0 . S. Department af Energy Contract No. $\mathrm{DE}-\mathrm{ACO} 2-76 \mathrm{CH} 03073$. 


\section{REFEREHCES}

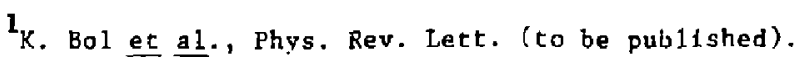

2K. Jaehnig, R. Fonck, K. Ida, and E. Powe11, Rev. Sci. Instrum. $\underline{56}(5$, Part II), 865 (1985).

${ }^{3}$. Kaita, R. Gcldston, D. Meyerhofet, and J. Etidon. Rev. Sci. Instrum. $52(12), 1795(1981)$.

4. Fonck, A. Ramsey, and R. Yelle, Appl. Optics 21 (3), 2115 $(1982)$.

$5_{S}$. Davis, D. Mueller, and C. Keane, Rev. Sci. Instrum. 54 (3), $315(1983)$ 


\section{PIGUKE CAPTIONS}

1. CXRS central toroidal rotation velocity (a) and central ion temperature (b) vs. time during sawteech. Also shown are plots of the raw data with their corresponding Gaussian line fits for two particular times, juse before (c) and after (d) a sawtouth crast. The spectroneter was tuned to the $0^{7+} 1$ ine at 2976 Angstroms.

2. a. Flux and analyzer viewing energy us. time for FIDE, before sawtooth crash (A) and after erash (B).

b. FIDE flux vs, energy, corresponding to Fig. 2.a. corrected for analyzer efficiency and bandwidth, before crash ( 3.5 keV) and after crash (2.6 keV). Sightline is near center.

3. a. CXRS $T_{i}(t)$. The CXRS line width decreased $15 \%$ after the crash, and the line center shifted $\approx 0.3 \AA$.

b. $T_{i}(t)$ along the three inetrumented FIDE sightlines for the same shot.

c. CXRS $T_{i}$ profiles before $(0)$ and after ( $)$ the sawtooth crash, generated by changing the spectrometer sightine over a series of shots. Also shown are the three FIDE sightiines before (0) and after $(X)$ the crash for one of the shotg in the series.

4. Upper flgure shows flux vs. energy for the three FIDE sightlines. The sightliies move progressively from the center (uppermost curve) to the edge (lowest eurve) of the plamma. Lower figure shows results of a Fokker-Planck model for the same three sightlines. The heavy lines are the regults with the heating beams on, and the light Iines are for no heating bearg. The lowest curve, for the sightline just grazing the edge of the plasma, is not affected by the heating beams. The data and the calculation with heating beams shon curvature in the energy spectrum, dut to slowing-down heating beam particles, over the same energy range. 


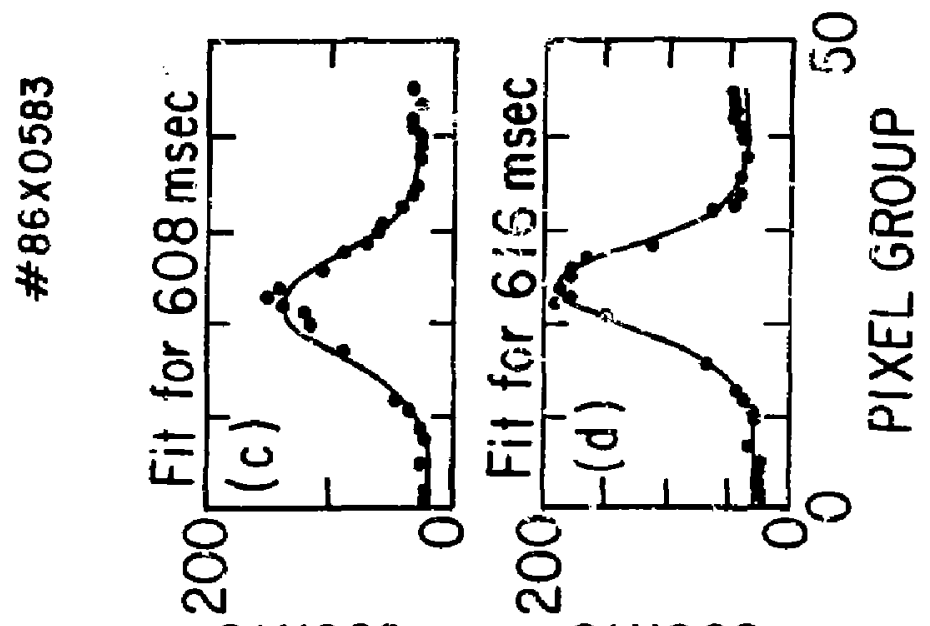

SINกOJ

SinnOJ

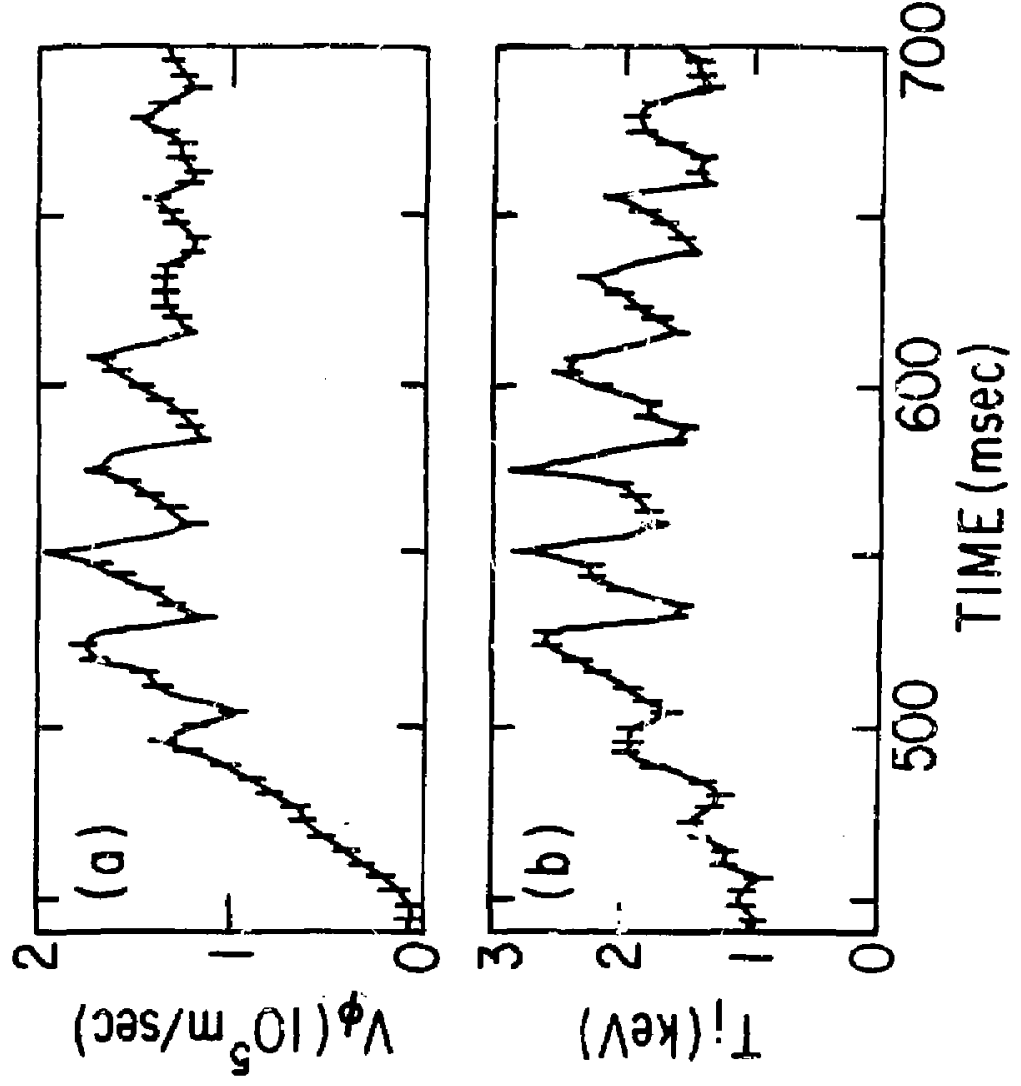




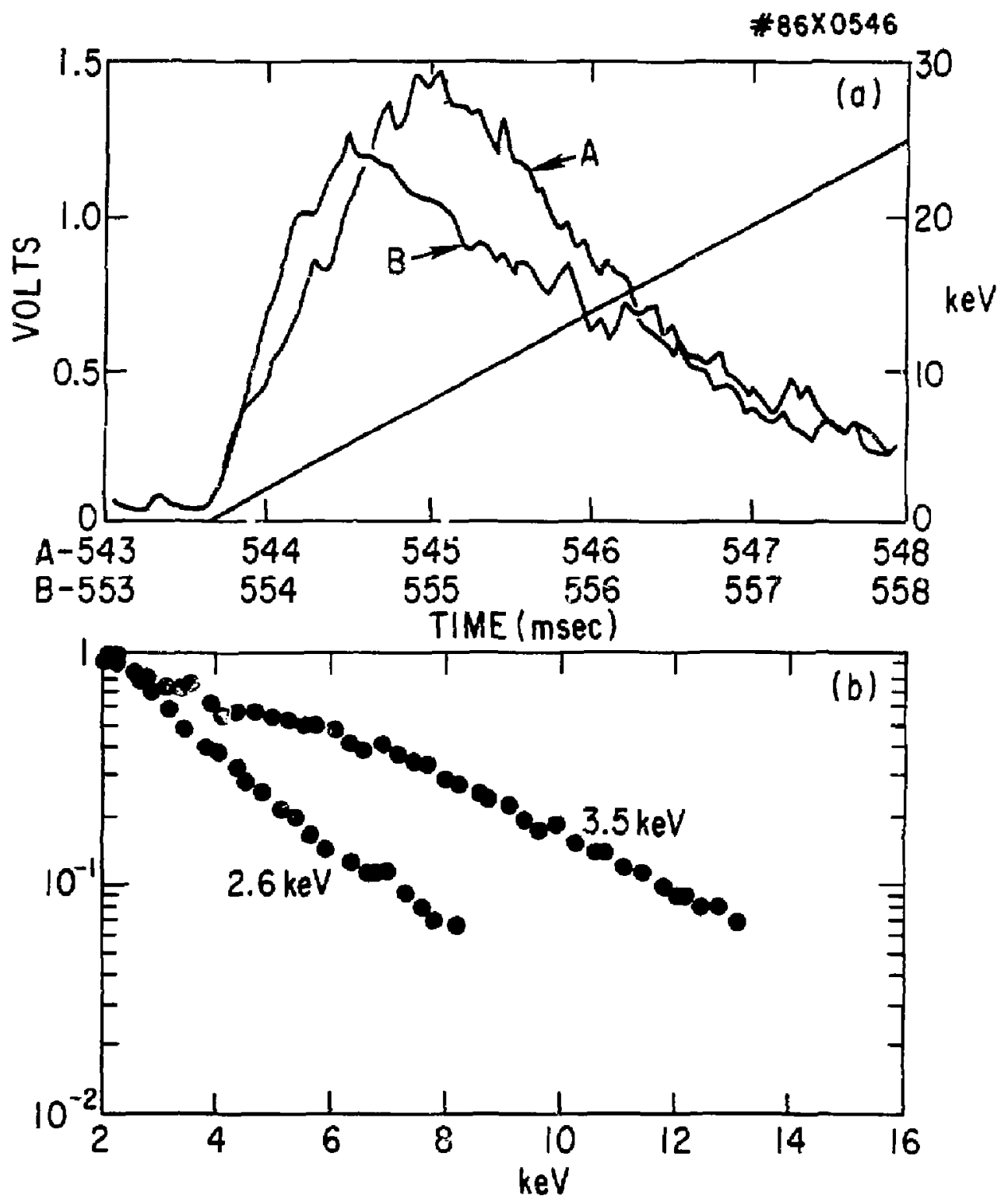

Fig. 2 

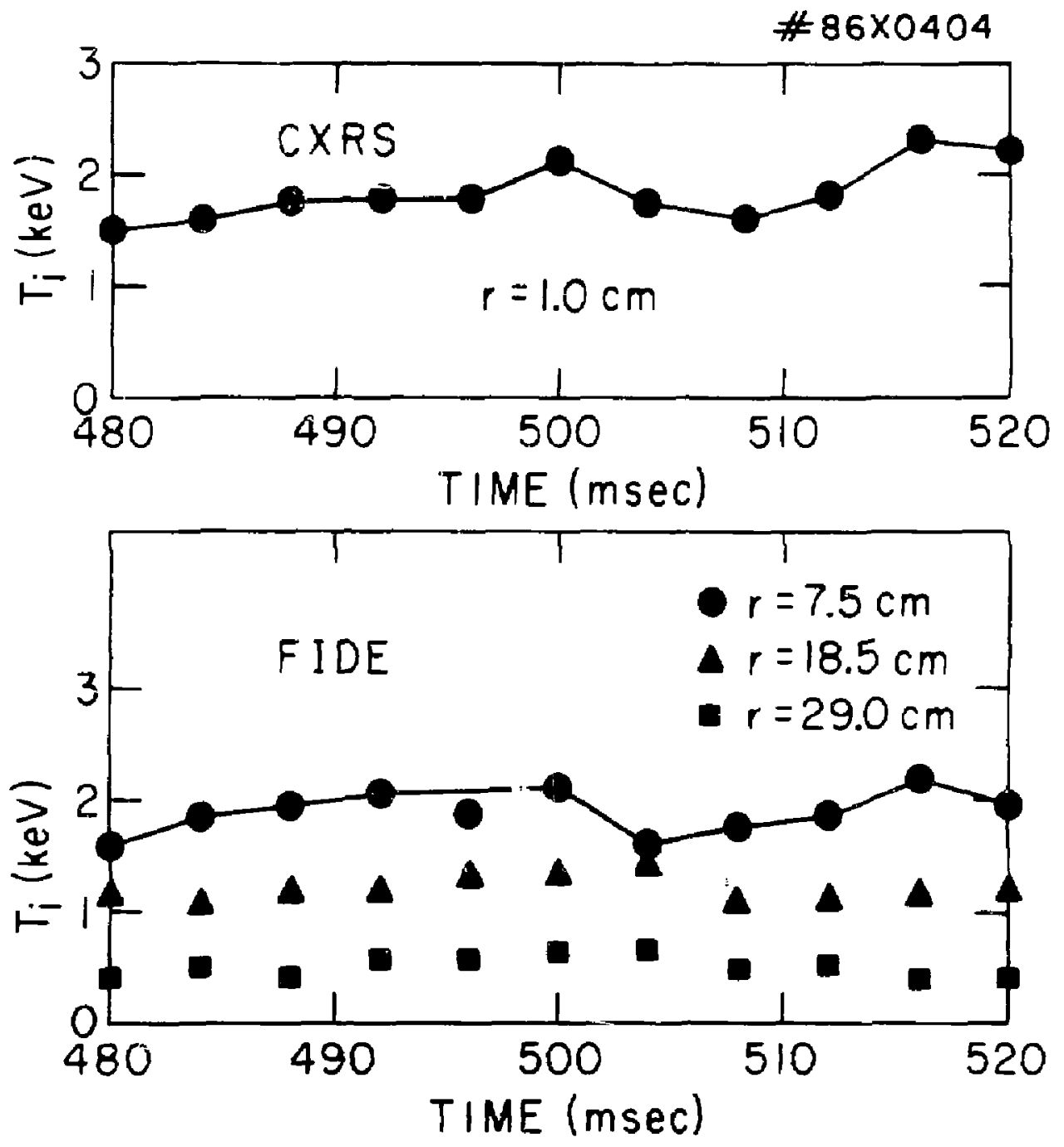

Fig. $3(a, b)$ 


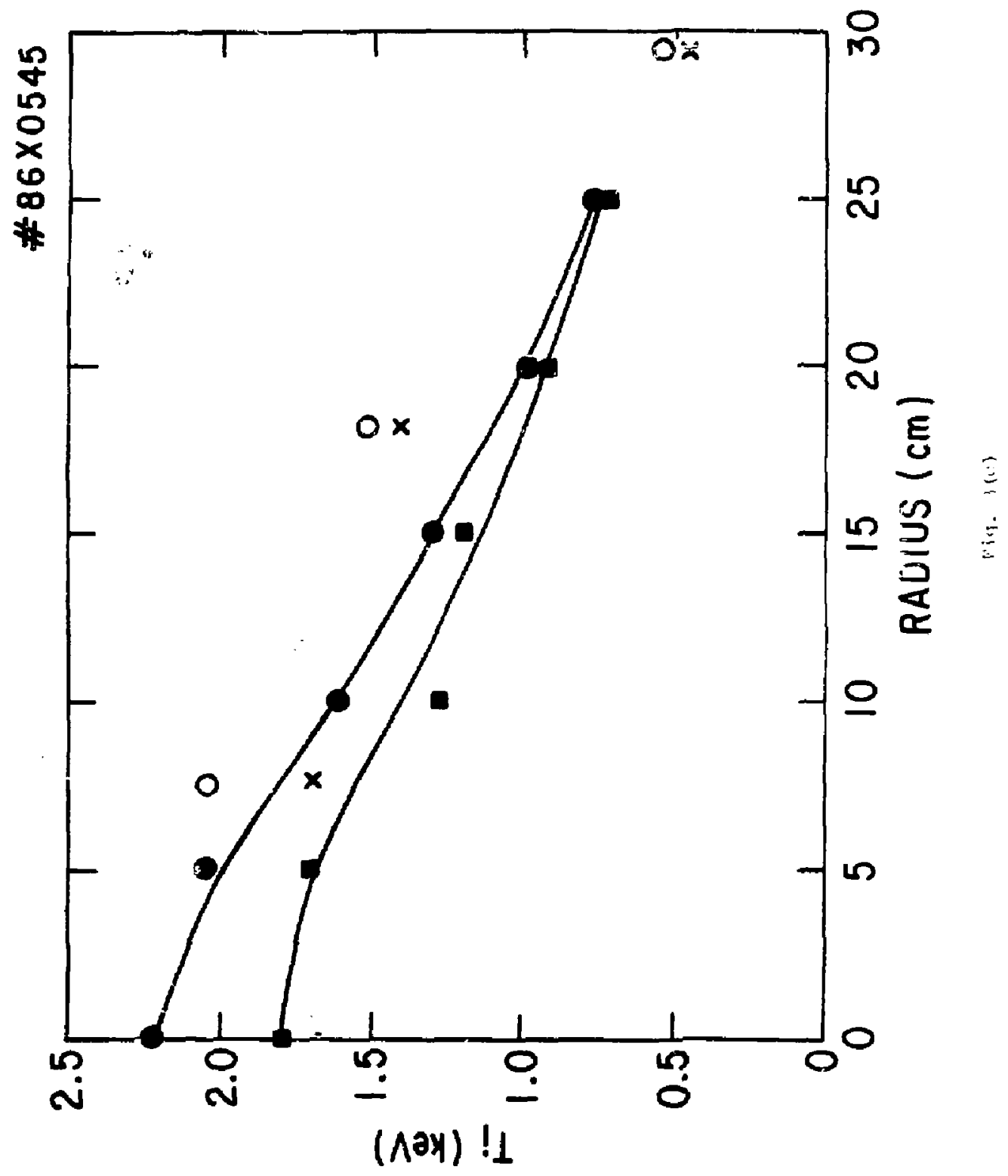



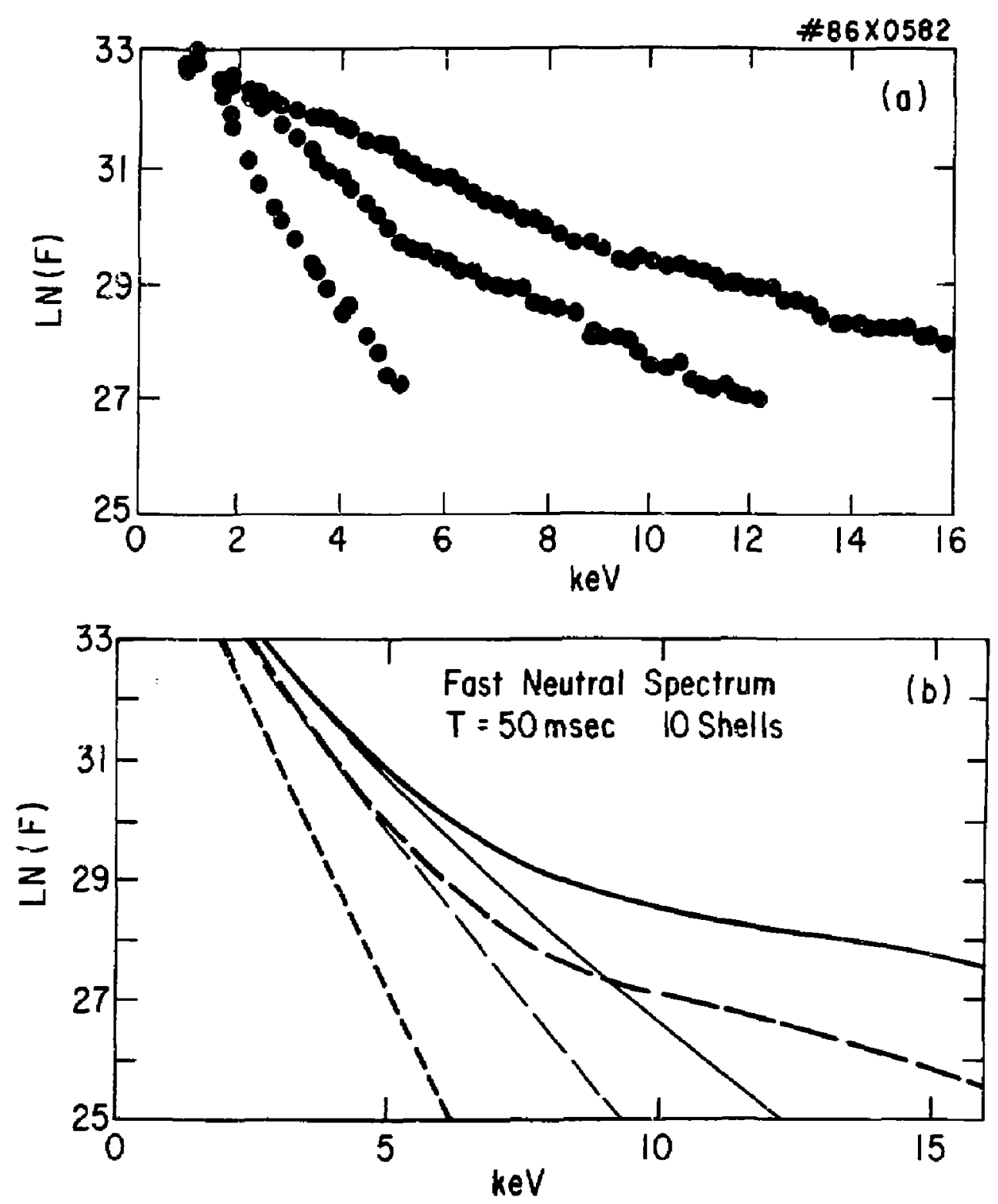

Fig. 4 
Plasma Ras Lab, Austra Nat'l Unly, AUSTRALiA

Dr. Frank J. Paoloni, Univ of Hollongong, AUSTRALIA

Prot. I.R. Jones, FIInders UnIV.., AUSTRALIA

Prof. M.H. Brennan, Unlv Sydney, AUSTRALIA

Prot, F. Cap, Inst Thoo Phys, AustRIA

M. Goossens, Astronomisch InstituUt, BELGIUH

Praf. R, Gouclque, Laboratorlum yoor Natuurkunde, BELilum

Dr. D. Palumbo, Dg XII Fusian Prog, Belgium

Ecole Royale MIlitalire, Lab de Phys Plasmas, BELGI UN

Dr. P.H. Sakanaka, Univ Estadua1, BRRZ IL

Lib, \& Doc. Div., Instituto de Pesqulsos Espaclala, BRizIL

Or. C.R. James, Unly of Alberta, GANADA

Prof. J. Telchmenn, Univ of Montreal, CANADA

Or. H.M. Skarsgard, Unir of Saskatchewan, CANADA

Prot. S.R. Sraenivasan, University of Caigary, CANADA

Prof. Tudor W. Johnston, INRS-Energle, CANADA

Dr. Hannes Bernard, UnIv aritish Columbia, CANADA

Dr. H.P. Bachynskl, MB Techl.-logles. Inc., CANADA

Chalk Rivar, Nuel Lab, CANADA

Znengwu LI, SW inst Physlcs, CHINA

Library, Tsing Hud University, CHINA

Librarlan, Inetitute of Physlcs, CHINA

Inst Plasme Phys, heademla Sinleo, CHINA

Dr. Peter Lukac, Komenskeho UnIv, CECHOSLOVAKIA

The Librarlan, Culhan Laborotory, ENGLANO

Prot. Schatzmen, Obsorvatoira de Ni ce, FaAnce

J. Radot, CEN-tapa, FRANCE

JET Roeding Roan, JET Jolnt Undartaking, ENGLAND

M Oupas Llorary, M Dupes Llbrary, FRANCE

Dr. Tom Hual, Acaciemy Bibllographlc, HONG KONG

Preprint Library, Gent Res Inst Phys, HUNGARY

Dr. R,K. Ghhajlan I, VIkram Univ, INDIA

Dr. B. Dasgupta, Saha Inst, INDIA

Dr. P. Kan, Physleal Research Lab, IND!A

Dr. Phililo Rosenau, Isruel Inst Tech, ISRAEL

Prof. S. Cuporman, Tol Aviv Univarsity, ISRAEL

Prot. G. RostognI, Un IV DI Padove, ITALY

Librarian, Intil Ctr Theo Phys, ITALY

Miss Clol ta De Palor Assoc EURATOM-ENEA, ITALY

Bl blloteca, def CNR EURATOA, ITALY

Dr. H. Yameto, ToshIbe Res Dav, JAPAN

Diroc. Dopt, Lg. Tokomek Dor. JAERI, JAPAN

Prof. Nobuyuki Inowe, University of Tokyo, JAPAk

Research Into Conter, Nagoyo Unlversity, JAPAN

Prof. Kyojl NIshlkawa, Unlv of Hiroshlmb, JAPAN

Prof. SIgers Horl, JAERI, JAPAN

Prof. 5. Tanaka, Kyoto Ualverslty, JAPAN

Llbrary, Kyoto UnIyersity, JAPAN

Prof. Iehlro Karakaml, NIhor Univ, JAPAN

Prot, 5atosht Iroh, Kyusitc Unlversity, JAPAN

Dr. D.l. Chol, Adv, Inst Scl \& Tech, KOREs

Toen Into DIvlsion, KAERI, KOREA
Bibllothek, Fom-Inst Voor Piasma, NETHERLANDS

Prot. B.5. LIley, University of Walkato, MEW ZEALAND

Prot. J.A.C. Cobral, Inst Super lor Teen, PORT JGRL

Dr. Octovian Petrus, ALt CLLA UnIversity, ROMANIA

Prof. M.A. Hell barg, Unlyersity of Natal, SO AFRICA

Dr. Johan de Villlers, Plasma Physles, Nucor, SO AFRlaz

Fusion DIY. Librery, JEN, SPAIN

Prof. Hans Wlihalmson, Chalmars Univ Taen, SwEDEN

Dr. Lennart Stenflo, UnIversity of JMEA, SWECEN

Library, Royal Inst Toch, SwEDEN

Centre de Recherchesen, Ecole Polytech Fed, SHITZERLANO

Dr. V.T. Tolok, Kharkoy Phys Toch Ins, USSR

Dr. D.D. Ryutov, SIberlan Acod Sel, USSR

Dr. G.A. Ellseov, Kurchator Institute, USSR

Or. Y.A. Glukhlkh, Inst Electro-Physical, USSR Institute Een. Physlas, USSR

Prof, T,J.H, Boyd, UnIr College $N$ wales, wales Or. K. Schindter, Ruhr Unluersltat, W. GERMANY ASDEX Reading Rm, IPPMax-lanck-institut fur

Plasmaphys|k, F,R,G.

Nuclaar Ros Estab, Jullch Ltd, W. GERMANY

Liorarlan, Max-Planck instltut, H. GeRMANY aiollothek, Inst Plassi=torschung, W. GERMANY

Prof, R.K. Janev, Inst Fhys, YugOSLAVIA

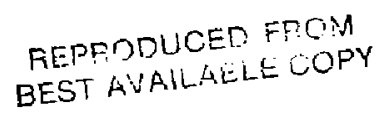

